九州大学学術情報リポジトリ

Kyushu University Institutional Repository

Analysis of Tree-ring Chemistry to Interpret Variations in Tree-ring Growth of Larix leptolepis and Cryptomeria japonica in Relation to Atmospheric Environmental Changes in Southern Korea

Lee, Kye-Han

Department of Forestry, Chonnam National University

Luong, Thi-Hoan

Department of Forestry, Chonnam National University

Jang, Kyoung-Soo

Department of Forestry, Chonnam National University

Choi, Woo-Jung

Department of Rural and Biosystems Engineering, Chonnam National University

他

https://doi.org/10.5109/1526293

出版情報：九州大学大学院農学研究院紀要. 60 (1)，pp.33-42，2015-02-27. Faculty of Agriculture， Kyushu University

バージョン :

権利関係 : 


\title{
Analysis of Tree-ring Chemistry to Interpret Variations in Tree-ring Growth of Larix leptolepis and Cryptomeria japonica in Relation to Atmospheric Environmental Changes in Southern Korea
}

\author{
Kye-Han LEE ${ }^{1}$, Thi-Hoan LUONG ${ }^{1}$, Kyoung-Soo JANG ${ }^{1}$, Woo-Jung $\mathrm{CHOI}^{2}$, \\ Gwan-Soo PARK ${ }^{3}$ and Shoji OHGA* \\ Laboratory of Forest Resources Management, Division of Forest Environmental Sciences, \\ Department of Agro-Environmental Sciences, Faculty of Agriculture, \\ Kyushu University, Fukuoka 811-2415, Japan \\ (Received October 23, 2014 and accepted November 14, 2014)
}

\begin{abstract}
Annual tree rings may have information to help investigate the effects of environmental change caused by temperature, air pollution, and acid rain on tree growth. Annual tree ring growth in relation to environmental changes was studied by analysing the chemistry of tree rings of Larix leptolepis (L. leptolepis) and Cryptomeria japonica (C. japonica) in southern Korea. Tree ring growth (diameter, annual increments of ring area) and tree ring chemistry $\left(\delta^{13} \mathrm{C}, \delta{ }^{15} \mathrm{~N}, \mathrm{~N}\right)$ concentration, and $\mathrm{Ca} / \mathrm{Al}$ ratios of both species were analysed. Regression analysis was conducted between tree ring data and environmental variables. Annual tree ring growth significantly differed between the two species and increased over time $(p<0.01)$. The growth rate of L. leptolepis (ring width and ring area) was lower than that of $C$. japonica. Temperature, $\mathrm{CO}_{2}, \mathrm{NO}_{2}$, and $\mathrm{SO}_{2}$ affected $(p<0.05)$ the tree ring area increment of $C$. japonica, and $\mathrm{SO}_{2}$ affected $(p<0.05)$ the tree ring area increment of $L$. leptolepis. The relationships of temperature, $\mathrm{SO}_{2}$, and $\mathrm{NO}_{2}$ concentrations with tree ring $\delta{ }^{13} \mathrm{C}$ of both species $(p<0.05)$ increased $\mathrm{C}$ isotope discrimination $(\Delta)$ and affected tree ring growth. There was a negative correlation between annual ring area and $\Delta$ in tree rings of $L$. leptolepis $(p<0.01)$. For $C$. japonica, $\Delta$ was positively correlated $(p<0.01)$ with annual ring area. The correlation of precipitation $\mathrm{pH}$ with tree ring $\delta{ }^{13} \mathrm{C}, \delta{ }^{15} \mathrm{~N}$, and $\mathrm{N}$ concentration of the two species $(p<0.01)$ could provide information on $\mathrm{N}$ deposition due to the $\mathrm{H}^{+}$input from acid rain. Tree ring $\delta^{15} \mathrm{~N}$ and $\mathrm{N}$ concentration may be useful as indicators for precipitation $\mathrm{pH}$. Tree ring growth was influenced by climate change, atmosphere pollutants and precipitation $\mathrm{pH}$. The effects of increased temperature, atmosphere pollutants, and acid precipitation on radial growth may reflect $\mathrm{N}$ deposition from fossil fuel combustion. Acid deposition at the study site affected tree ring growth and both species may be at risk from the long-term effects of acid deposition over time.
\end{abstract}

Key words: acid precipitation, annual tree ring, climate change, $\delta{ }^{13} \mathrm{C}, \mathrm{N}$ deposition, $\delta{ }^{15} \mathrm{~N}$

\section{INTRODUCTION}

Tree growth is affected by various environmental factors associated with climate change, including air temperature, precipitation, and air pollution (Chmura et al., 2011). Information on annual tree rings can be used to estimate their environmental history to understand the effects of environmental changes on forests (Choi and Lee, 2012). Environmental change can either constrain or stimulate tree ring growth (Choi et al., 2005b). Forest decline in Asia has been linked to acid precipitation (Hirano et al., 2007), air pollution and global warming (Kume et al., 2000; Woo, 2009).

Impacts of atmospheric $\mathrm{NO}_{2}$ concentration on forest decline of Pinus densiflora in Japan have been reported by Kume et al. (2000). A threat to Cryptomeria japonica and Chamaecyparis obtusa forests in Japan from soil acidification caused by increased nitrogen deposition has also been noted (Ito et al., 2011). Effects of

\footnotetext{
Department of Forestry, Chonnam National University, Gwangju 500-757, Korea

Department of Rural and Biosystems Engineering, Chonnam National University, Gwangju 500-757, Korea

3 Department of Forestry Resources, Chungnam National University, Daejeon 305-764, Korea

* Corresponding Author (E-mail: ohga@forest.kyushu-u.ac.jp)
}

precipitation $\mathrm{pH}$ on decreased tree-ring growth of $P$. densiflora due to $\mathrm{N}$ deposition have been reported by Choi et al. (2005b), Kwak et al. (2009a; 2009b; 2011), and Lee et al. (2011).

Annual tree rings were also used to estimate historical temperature, and the effects of air pollution and precipitation pH (Seftigen et al., 2011; Choi et al., 2005b; Bukata and Kyser, 2007). The temperature influenced $\delta^{13} \mathrm{C}$ via the photosynthetic rate due to increased atmospheric $\mathrm{CO}_{2}$ concentration (Chmura et al., 2011; Seftigen et al., 2011). The effects of air pollution on $\delta{ }^{13} \mathrm{C}$ resulted from reduced $\mathrm{CO}_{2}$ concentration in the intercellular air spaces caused by stomatal closure (Martin and Sutherland, 1990). Precipitation $\mathrm{pH}$ and $\mathrm{H}^{+}$from acid rain affected $\delta{ }^{13} \mathrm{C}$ via the carboxylation rate (Shan, 1998; Kwak et al., 2009b). Therefore, the relative abundance of $\delta{ }^{13} \mathrm{C}$ in tree ring tissue can serve as a time integrating indicator of photosynthetic response to environmental conditions and is linked to changes in stomatal conductance and the carboxylation rate (Farquhar et al., 1989; Viet et al., 2013).

In addition, the correlation between $\mathrm{N}$ concentration and $\delta{ }^{15} \mathrm{~N}$ in tree rings with precipitation acidity provides isotopic evidence of the contribution of atmospheric nitrogen deposition (Kwak et al., 2009a; 2009b). $\quad \delta^{15} \mathrm{~N}$ of tree rings can be used to estimate historical changes of pre- 
cipitation $\mathrm{pH}$, while nitrogen concentration in tree rings is not a useful indicator for acid precipitation (Kwak et al., 2011). A pattern of increasing $\mathrm{N}$ concentration with decreasing $\delta^{15} \mathrm{~N}$ in tree rings has been attributed to increased N deposition (Poulson et al., 1995; Bukata and Kyser, 2007; Choi et al., 2007; Kwak et al., 2011). Although $\mathrm{N}$ deposition can improve tree growth in a short term due to the $\mathrm{N}$ fertilizer effect, $\mathrm{N}$ deposition over decades can lead to nutrient deficiency and imbalance, and tree decline (Shortle et al., 1995; Tomlinson, 2003).

Decreased $\mathrm{Ca} / \mathrm{Al}$ in tree rings associated with a decreasing precipitation $\mathrm{pH}$ may reflect reduction in $\mathrm{Ca}$ availability due to soil acidification (Kwak et al., 2009b; Kwak et al., 2011). The ratio of $\mathrm{Ca} / \mathrm{Al}$ in tree rings of $P$. densiflora was a useful predictor of historical acid precipitation (Kwak et al., 2011; Lee et al., 2011). Although some studies have reported the effects of environment factors on tree ring chemistry of $P$. densiflora in Korea (Choi et al., 2005b; Kwak et al., 2009b; Kwak et al., 2011), no study has been conducted for Japanese larch (Larix leptolepis) and Japanese cedar (Cryptomeria japonica), major species planted in Korea.

The aims of this study were to examine the effects of environmental changes on tree ring growth of Japanese larch and cedar forests and to determine the relationships between tree-ring parameters $\left(\delta^{13} \mathrm{C}, \delta{ }^{15} \mathrm{~N}, \mathrm{~N}\right.$ concentration, and $\mathrm{Ca} / \mathrm{Al}$ in tree rings) and precipitation $\mathrm{pH}$.

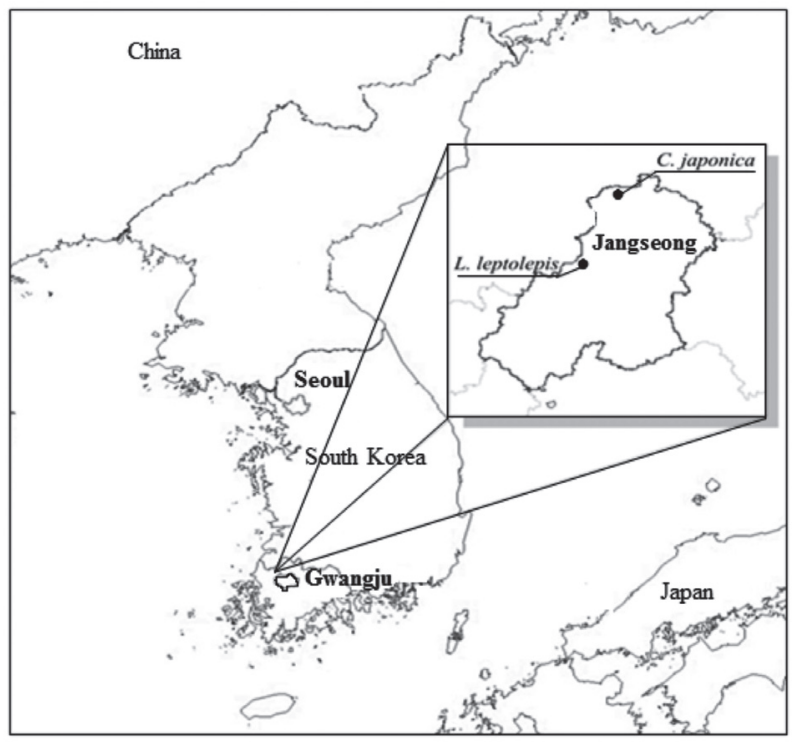

Fig. 1. Geographical locations of the study sites.

\section{MATERIALS AND METHODS}

\section{Study area}

The study site is located in Jangseong County in South Korea, approximately $35 \mathrm{~km}$ north of Gwangju city (Fig. 1). It is in a typical rural area; $63 \%$ is mountainous. The research plots were located at $35^{\circ} 22^{\prime} 38^{\prime \prime} \mathrm{N}, 126^{\circ}$ $44^{\prime} 13^{\prime \prime} \mathrm{E}, 488 \mathrm{~m}$ a.s.l with 20o slope for L. leptolepis and $35^{\circ} 27^{\prime} 19^{\prime \prime} \mathrm{N}, 126^{\circ} 47^{\prime} 01^{\prime \prime} \mathrm{E}, 218 \mathrm{~m}$ a.s.l with $15^{\circ}$ slope for C. japonica. The soils are classified as shallow gravelly silt loam, with a thin brown to dark brown color and a $\mathrm{pH}$ range of 4.00 to 4.35 . Total $\mathrm{N}$ was $3.1 \mathrm{~g} \mathrm{~kg}^{-1}$ for $C$. japonica and $3.7 \mathrm{~g} \mathrm{~kg}^{-1}$ for L. leptolepis (Table 1).

All meteorological and environmental monitoring data were obtained at the Gwangju monitoring station, located about $30 \mathrm{~km}$ south of the site (Ministry of Environment of Korea, 2010). Climate data were available from 1962 to 2009. The mean annual temperature and precipitation during this period were $13.5^{\circ} \mathrm{C}$ and $1,364.7 \mathrm{~mm}$, respectively (Fig. 2a). Mean precipitation $\mathrm{pH}$ showed a decrease from 5.5 to 4.9 between 1992 and 2009 (Fig. 2b). Atmospheric pollutants' $\left(\mathrm{NO}_{2}, \mathrm{SO}_{2}\right.$, and $\left.\mathrm{O}_{3}\right)$ concentration data were measured from 1989 to 2009. During this period, $\mathrm{SO}_{2}$ concentration decreased from 21.0 to $4.0 \mathrm{~nL}$ $\mathrm{L}^{-1}$, and mean annual concentrations of $\mathrm{O}_{3}$ and $\mathrm{NO}_{2}$ increased from 7.0 to $26.0 \mathrm{~nL} \mathrm{~L}^{-1}$ and from 11.0 to $21.0 \mathrm{~nL}$ $\mathrm{L}^{-1}$, respectively (Fig. 2c). Atmospheric $\mathrm{CO}_{2}$ concentra-
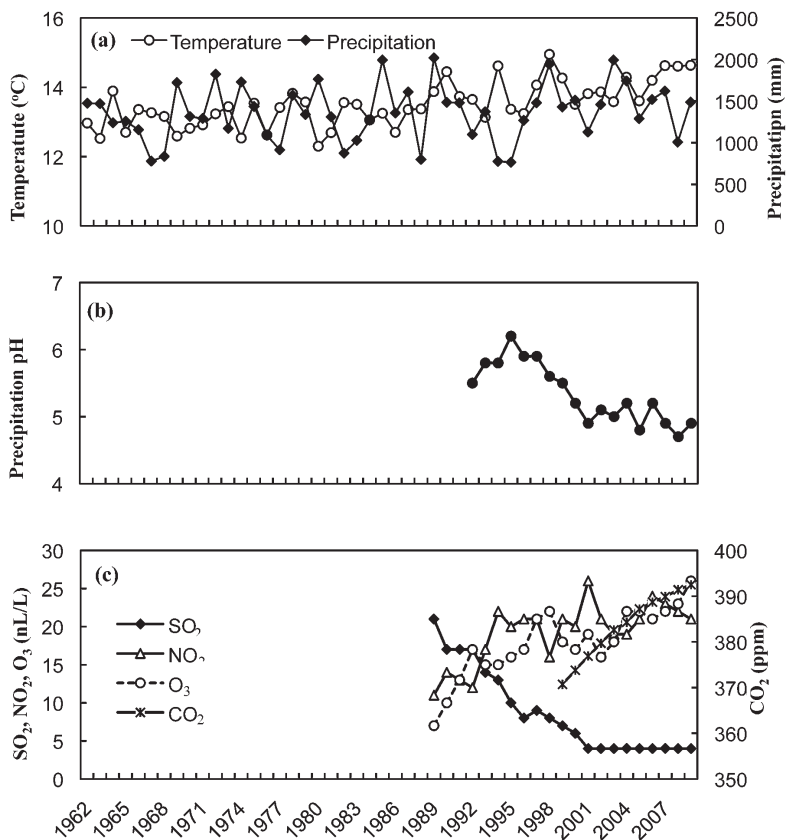

Fig. 2. Changes in mean annual temperature and precipitation (a), mean annual precipitation $\mathrm{pH}$ (b), concentration of atmospheric pollutants $\left(\mathrm{SO}_{2}, \mathrm{NO}_{2}, \mathrm{O}_{3}\right.$ and $\left.\mathrm{CO}_{2}\right)$ (c) in the study area. Data were available for those periods.

Table 1. Characteristics of location and soil chemical properties in the study sites

\begin{tabular}{|c|c|c|c|c|c|c|}
\hline Species & $\begin{array}{l}\text { Latitude } \\
(\mathrm{N})\end{array}$ & $\begin{array}{l}\text { Longitude } \\
\text { (E) }\end{array}$ & $\begin{array}{l}\text { Altitude } \\
\text { (m a.s.l) }\end{array}$ & Slope & $\mathrm{pH}$ & $\begin{array}{l}\text { Total N } \\
\left(\mathrm{g} \mathrm{kg}^{-1}\right)\end{array}$ \\
\hline L. leptolepis & $35^{\circ} 22^{\prime} 38^{\prime \prime}$ & $126^{\circ} 44^{\prime} 13^{\prime \prime}$ & 488 & $20^{\circ}$ & $4.00 \pm 0.01$ & $3.68 \pm 0.27$ \\
\hline C. japonica & $35^{\circ} 27^{\prime} 19^{\prime \prime}$ & $126^{\circ} 47^{\prime} 01^{\prime \prime}$ & 218 & $15^{\circ}$ & $4.35 \pm 0.03$ & $3.09 \pm 0.38$ \\
\hline
\end{tabular}


tion increased from $370.7 \mathrm{ppm}$ in 1999 to $389.9 \mathrm{ppm}$ in 2009 (Fig. 2c).

\section{Annual tree-ring analysis}

A $20 \times 20 \mathrm{~m}$ plot for each species was established at the study site. For each species, three tree-ring disks at breast height were randomly selected from the plots. The ages of these disks ranged from 42 to 46 years old for $L$. leptolepis and from 32 to 34 years old for C. Japonica (Table 2).

The disks were sanded and polished. Annual increments of diameter growth were measured on four radii and a mean calculated. The mean annual diameter increment was $0.73 \mathrm{~cm} \mathrm{yr}^{-1}$ for C. japonica and $0.50 \mathrm{~cm} \mathrm{yr}^{-1}$ for L. leptolepis; mean tree-ring width was $3.66 \mathrm{~mm}$ for C. japonica and $2.47 \mathrm{~mm}$ for L. leptolepis (Table 2). It was then assumed that tree rings are concentric circles (Choi et al., 2007). The radii were cross-dated to identify the exact year each tree ring was formed. Ring widths were measured to an accuracy of $0.01 \mathrm{~mm}$ using CDendro and CooRecorder 7.4 software (Cybis Elektronik and Data AB, Salsjobden, Sweden). Foliage samples were collected from trees sampled for ring disks. The wooden disks and foliar samples were oven-dried at $60^{\circ} \mathrm{C}$ to constant weight.

\section{Chemical analysis}

The wood samples were used for chemical analyses after being ground to fine powder with a centrifugal mill (MM200, Retsch GmbH, Haan, Germany). The $\delta{ }^{13} \mathrm{C}$, $\delta^{15} \mathrm{~N}$, and $\mathrm{N}$ concentration were determined using a continuous-flow stable isotope ratio mass spectrometer linked to an elemental analyzer (Iso Prime-EA, Micromass, UK) (Kwak et al., 2009b). In this study, whole-plant tissue samples, instead of cellulose, were used for isotope analysis, because for trees, whole-plant tissue produces the same $\delta{ }^{13} \mathrm{C}$, as well as $\delta{ }^{15} \mathrm{~N}$, as cellulose (Loader et al., 2003). Whole wood samples can be successively used in tree ring isotope studies as in dendrochronology studies, not the exact value of any individual ring (McCarroll and Loader 2004). Carbon and nitrogen isotope composition $(\delta$ ) were calculated as:

$$
\delta(\%)=\left[\left(\mathrm{R}_{\text {sample }} / \mathrm{R}_{\text {standard }}\right)-1\right] \times 1000
$$

where, $R_{\text {sample }}$ and $R_{\text {standard }}$ are the ${ }^{13} \mathrm{C} /{ }^{12} \mathrm{C}$ or ${ }^{15} \mathrm{~N} /{ }^{14} \mathrm{~N}$ ratios in a sample and standard, respectively. The standards are the Pee Dee Belemnite (PDB) standard for C and atmospheric $\mathrm{N}_{2}$ for nitrogen. The analytical error for carbon isotopes was $< \pm 0.1 \%$ and for nitrogen isotopes less $< \pm$
$0.2 \%$.

Carbon isotope discrimination $(\Delta)$ was measured using the following equation (Farquhar et al., 1989):

$$
\Delta=\mathrm{a}+(\mathrm{b}-\mathrm{a}) \mathrm{C}_{\mathrm{i}} / \mathrm{C}_{\mathrm{a}}=\left(\delta^{13} \mathrm{C}_{\text {air }}-\delta^{13} \mathrm{C}_{\text {plant }}\right) /\left(1+\delta{ }^{13} \mathrm{C}_{\text {plant }} / 1000\right)
$$

Where, $\Delta$ is the carbon isotope discrimination; the $\delta{ }^{13} \mathrm{C}_{\text {airf }}$ or each year $(\mathrm{t})$ was obtained from the regression equation of Feng (1998):

$$
\delta{ }^{13} \mathrm{C}_{\text {air }}=-6.429-0.006 \exp [0.0217(\mathrm{t}-1740)]
$$

According to this equation, $\delta{ }^{13} \mathrm{C}_{\text {air }}$ decreased from $-7.17 \%$ in 1962 to $-8.40 \%$ in 2007 for L. leptolepis and from $-7.48 \%$ in 1978 to $-8.49 \%$ in 2009 for C. japonica. The $\delta{ }^{13} \mathrm{C}$ plant is determined by the $\delta{ }^{13} \mathrm{C}$ of atmospheric $\mathrm{CO}_{2}$ and the ratio $\left(\mathrm{C}_{\mathrm{i}} / \mathrm{C}_{\mathrm{a}}\right)$ of intercellular $\left(\mathrm{C}_{\mathrm{i}}\right)$ to atmospheric $\left(\mathrm{C}_{\mathrm{a}}\right)$ partial pressure, as described as (Farquhar et al., 1989):

$$
\delta{ }^{13} \mathrm{C}_{\text {plant }}=\delta{ }^{13} \mathrm{C}_{\text {air }}-\mathrm{a}-(\mathrm{b}-\mathrm{a}) \mathrm{C}_{\mathrm{i}} / \mathrm{C}_{\mathrm{a}}(4)
$$

where, $\mathrm{a}$ and $\mathrm{b}$ are the discrimination against ${ }^{13} \mathrm{C}$ during $\mathrm{CO}_{2}$ diffusion through stomata (normally $\sim 4.4 \%$ ) and during $\mathrm{CO}_{2}$ fixation (normally $\sim 27 \%$ ) ), and $\mathrm{C}_{\mathrm{i}} / \mathrm{C}_{\mathrm{a}}$ is the ratio of intercellular to atmospheric $\mathrm{CO}_{2}$ concentration.

For tree-ring samples where $\mathrm{N}$ concentration was too low to be analyzed for both $\delta^{13} \mathrm{C}$ and $\delta{ }^{15} \mathrm{~N}$ simultaneously using peak jumping, the $\delta^{15} \mathrm{~N}$ was analyzed again by optimizing the mass spectrometer for $\delta^{15} \mathrm{~N}$ alone (Kwak et al., 2011; Choi et al., 2007). In this case, up to $10 \mathrm{mg}$ of wood samples were used, depending on the $\mathrm{N}$ concentration to meet a minimum $\mathrm{N}$ amount to improve the reproducibility of the $\delta^{15} \mathrm{~N}$ analysis (Choi et al., 2007).

To determine $\mathrm{Ca}$ and $\mathrm{Al}$ concentration, $0.5 \mathrm{~g}$ of wood sample was digested in $10 \mathrm{ml}$ concentrated $\mathrm{HNO}_{3}-\mathrm{HClO}_{4}-$ $\mathrm{H}_{2} \mathrm{SO}_{4}$ mixture $(1: 8: 1)$ at $200^{\circ} \mathrm{C}$ for $2 \mathrm{~h}$ on a heating block (Kwak et al., 2009a; Kwak et al., 2011). For Ca and Al, concentrations were analyzed using an inductively coupled plasma emission spectrophotometer.

\section{Statistical analysis}

Response and correlation function analyses were used to examine relationships between tree ring parameters and climate variables (temperature and precipitation), atmospheric pollutants $\left(\mathrm{SO}_{2}, \mathrm{NO}_{2}, \mathrm{O}_{3}\right.$, and $\left.\mathrm{CO}_{2}\right)$, and precipitation $\mathrm{pH}$. Response function analysis is a form of multiple regression. These relationships were explored by Pearson correlation analysis, because varia-

\begin{tabular}{|c|c|c|c|c|c|c|c|}
\hline \multirow[b]{2}{*}{ Species } & \multirow{2}{*}{$\begin{array}{c}\text { Tree } \\
\text { numbers }\end{array}$} & \multirow{2}{*}{$\begin{array}{l}\text { Ring numbers } \\
\text { (years) }\end{array}$} & \multirow{2}{*}{$\begin{array}{l}\text { Mean diameter } \\
(\mathrm{cm})\end{array}$} & \multirow{2}{*}{$\begin{array}{c}\text { Mean annual diameter } \\
\text { increment } \\
\left(\mathrm{cm} \mathrm{yr}^{-1}\right)\end{array}$} & \multirow{2}{*}{$\begin{array}{l}\text { Mean annual } \\
\text { ring width } \\
\text { (mm) }\end{array}$} & \multicolumn{2}{|c|}{ Foliage } \\
\hline & & & & & & $\mathrm{N}\left(\mathrm{g} \mathrm{kg}^{-1}\right)$ & $\delta^{13} \mathrm{C}(\%)$ \\
\hline L. leptolepis & 3 & 42 & $21.56 \pm 3.8$ & $0.50 \pm 0.03$ & $2.47 \pm 0.13$ & $28.50 \pm 0.39$ & $-26.79 \pm 0.16$ \\
\hline C. japonica & 3 & 32 & $24.14 \pm 3.4$ & $0.73 \pm 0.04$ & $3.66 \pm 0.16$ & $69.63 \pm 0.17$ & $-26.77 \pm 0.85$ \\
\hline
\end{tabular}
tion in tree-ring growth was likely to be affected by multiple environmental factors.

Table 2. Characteristics of tree ring growth and foliage in the study sites

Values are the mean $\pm \mathrm{SE}$ based on triplicated measurements. 
All the response and correlation functions were determined annually for the period 1966-2009, which was common to both tree-ring data and the regional climate records. For relationships of air pollutants with annual ring area and parameters in tree rings $\left(\delta^{13} \mathrm{C}, \delta{ }^{15} \mathrm{~N}, \mathrm{~N}\right.$ concentration and $\mathrm{Ca} / \mathrm{Al}$ ), the response and correlation functions were determined for $\mathrm{SO}_{2}, \mathrm{NO}_{2}$, and $\mathrm{O}_{3}$ from 1989 , for precipitation $\mathrm{pH}$ from 1992, and for $\mathrm{CO}_{2}$ concentration from1999.

All statistical analyses were performed using the SPSS 11.5 statistical software package (SPSS, Chicago, Illinois, USA). The level of significance for all statistical tests was an $\alpha$ value of 0.05 . The significance of annual trends of tree ring parameters was assessed by the analysis of time series using year as an independent variable.

\section{RESULTS}

\section{Variation in annual ring growth}

Annual radial growth rates were significantly different $(p<0.01)$ within a tree species and between the two
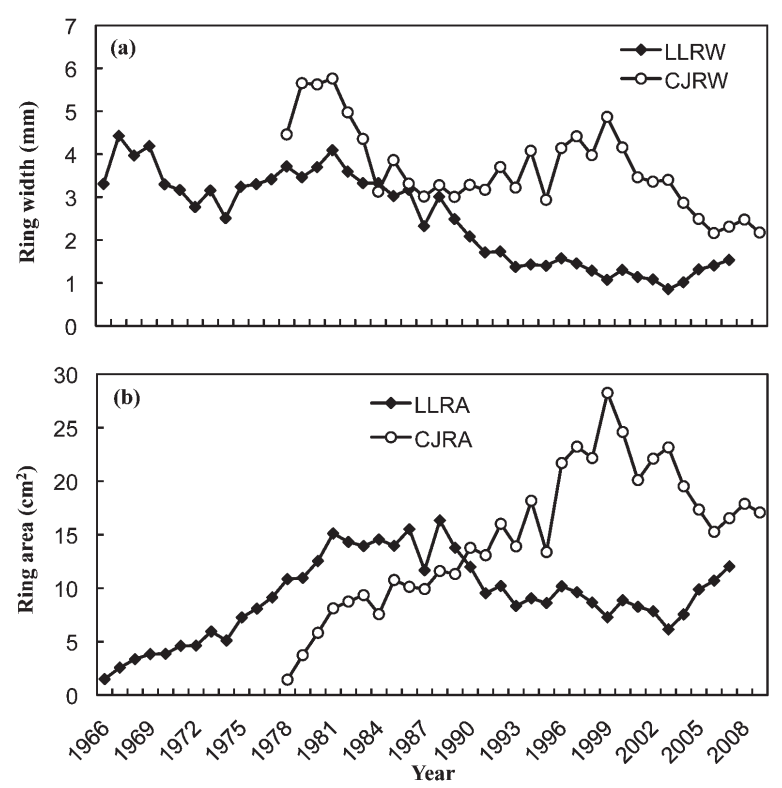

Fig. 3. Annual variation in ring width (a) and tree ring area (b) of two species. species. C. japonica had higher growth rates of ring width, ring area, and diameter increment than $L$. leptolepis (Fig. 3). Annual growth of ring widths of the two species decreased with time $(p<0.001)$ (Fig. 3a). Annual ring area of $L$. leptolepis and $C$. japonica increased until 1989 and 1998, respectively, and then decreased (Fig. 3b).

Temperature was positively $(p<0.01)$ correlated with annual ring area of $C$. japonica, but not of L. leptolepis (Table 3); no correlations were found between precipitation and annual ring area (Table 3). Annual ring growth of C. japonica was positively correlated with $\mathrm{NO}_{2}$ concentration $(\mathrm{p}<0.05)$ and negatively related with $\mathrm{SO}_{2}$ and $\mathrm{CO}_{2}$ concentrations $(p<0.01)$. Annual ring growth of $L$. leptolepis was positively correlated with $\mathrm{SO}_{2}$ concentration $(p<0.05)$ (Table 3).

\section{Tree ring $\delta{ }^{13} \mathbf{C}$}

Tree-ring $\delta{ }^{13} \mathrm{C}$ significantly decreased with time $(p<0.001)$ from $-25 \%$ to $-27.5 \%$ for L. leptolepis and from $-22.7 \%$ to $-25.2 \%$ for C. japonica (Fig. 4a). Mean
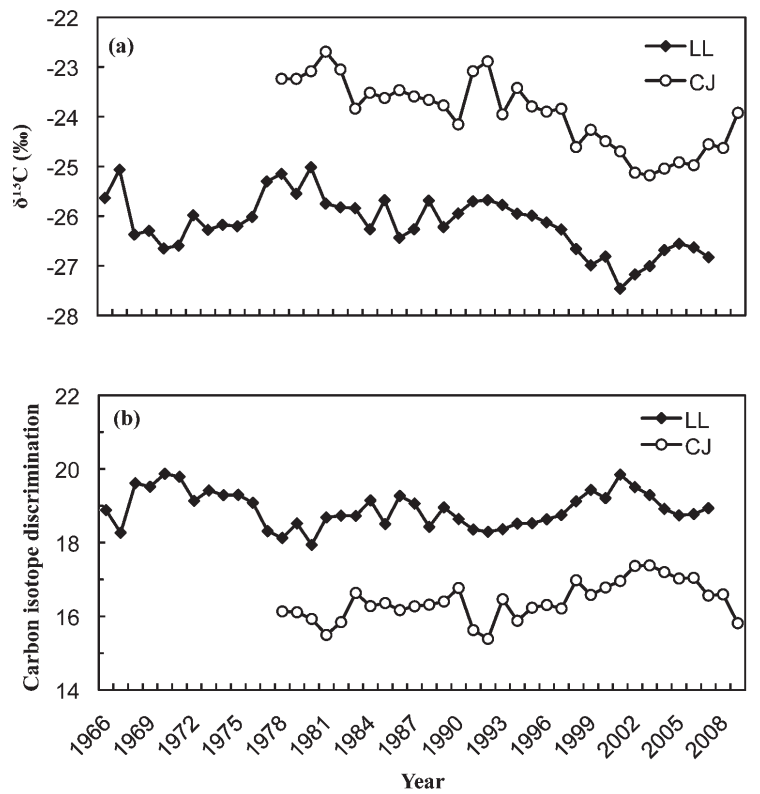

Fig. 4. Annual changes in $\delta{ }^{13} \mathrm{C}(\mathrm{a})$, carbon isotope discrimination (b) of two species.

Table 3. Pearson correlation of annual ring area of L. leptolepis and C. japonica with environmental variables in the study area

\begin{tabular}{|c|c|c|}
\hline \multirow{2}{*}{ Variable } & \multicolumn{2}{|c|}{ Pearson correlation coefficients } \\
\hline & L. leptolepis ${ }^{\mathrm{a}}$ & C. japonica ${ }^{\mathrm{a}}$ \\
\hline Temperature & $0.10^{\text {ns }}(42)$ & $0.49 * *(32)$ \\
\hline Precipitation & $0.04^{\text {ns }}(42)$ & $0.10^{\text {ns }}(32)$ \\
\hline Atmospheric $\mathrm{CO}_{2}$ concentration & $0.61^{\text {ns }}(9)$ & $-0.90 * * *(11)$ \\
\hline Atmospheric $\mathrm{NO}_{2}$ concentration & $-0.35^{\mathrm{ns}}(19)$ & $0.43 *(21)$ \\
\hline Atmospheric $\mathrm{SO}_{2}$ concentration & $0.52 *(19)$ & $-0.56 * *(21)$ \\
\hline Atmospheric $\mathrm{O}_{3}$ concentration & $-0.41^{\text {ns }}(19)$ & $0.38^{\text {ns }}(21)$ \\
\hline
\end{tabular}

Values in the parentheses are the number of data point used for the correlation analysis

${ }^{a}$ The mean values of three trees were used for tree variables in the correlation analysis

${ }^{\text {ns }}$ Not significant; ${ }^{* * *} p<0.001 ;{ }^{* *} p<0.01 ;{ }^{*} p<.05$. 
Table 4. Pearson correlation between $\delta{ }^{13} \mathrm{C}$ in annual tree ring of two species and environmental variables in the study area

\begin{tabular}{llc}
\hline \multicolumn{1}{c}{ Variable } & \multicolumn{2}{c}{ Pearson correlation coefficients } \\
\cline { 2 - 3 } & L. leptolepis ${ }^{\mathrm{a}}$ & C. japonica \\
\hline Temperature & $-0.31^{\mathrm{a}}(42)$ & $-0.48^{* *}(32)$ \\
Precipitation & $-0.26^{\mathrm{ns}}(42)$ & $-0.27^{\mathrm{ns}}(32)$ \\
Atmospheric $\mathrm{CO}_{2}$ concentration & $0.54^{\mathrm{ns}}(9)$ & $0.01^{\mathrm{ns}}(11)$ \\
Atmospheric $\mathrm{NO}_{2}$ concentration & $-0.62^{* *}(19)$ & $-0.53^{*}(21)$ \\
Atmospheric $\mathrm{SO}_{2}$ concentration & $0.80^{* * *}(19)$ & $0.77^{* * *}(21)$ \\
Atmospheric $\mathrm{O}_{3}$ concentration & $-0.47^{*}(19)$ & $-0.42^{\mathrm{ns}}(21)$ \\
\hline
\end{tabular}

Values in the parentheses are the number of data points used for the correlation analysis.

${ }^{a}$ The mean values of three trees were used for tree variables in the correlation analysis.

ns Not significant; *** $p<0.001 ; * * p<0.01 ; * p<0.05$

$\delta^{13} \mathrm{C}$ was less $(-26.2 \%)$ in $L$. leptolepis than $C$. japonica $\left(-23.9 \%\right.$ ). The $\delta{ }^{13} \mathrm{C}$ of both species was negatively $(p<0.05)$ correlated with temperature and $\mathrm{NO}_{2}$, and positively $(p<0.001)$ correlated with $\mathrm{SO}_{2}$ but there was no correlation with precipitation and $\mathrm{CO}_{2}$ concentration (Table 4). Atmospheric $\mathrm{O}_{3}$ concentration was correlated $(p<0.05)$ with tree-ring $\delta{ }^{13} \mathrm{C}$ of L. leptolepis but not of C. japonica (Table 4).

The patterns of $\Delta$ fluctuated within a narrow range between 17.94 to 19.87 for L. leptolepis and 15.39 to 17.38 for $C$. japonica (Fig. 4b) due to the inter-correlation between $\Delta$ and $\mathrm{C}_{\mathrm{i}} / \mathrm{C}_{\mathrm{a}}$ (see equation 2 ). Better tree growth of $C$. japonica was coupled with lower $\Delta$. The annual pattern of $\Delta$ of $C$. japonica was only correlated with $\mathrm{SO}_{2}$ concentration ( $p<0.01$, data not shown), and of L. leptolepis was correlated $(p<0.05)$ with $\mathrm{SO}_{2}, \mathrm{NO}_{2}, \mathrm{CO}_{2}$
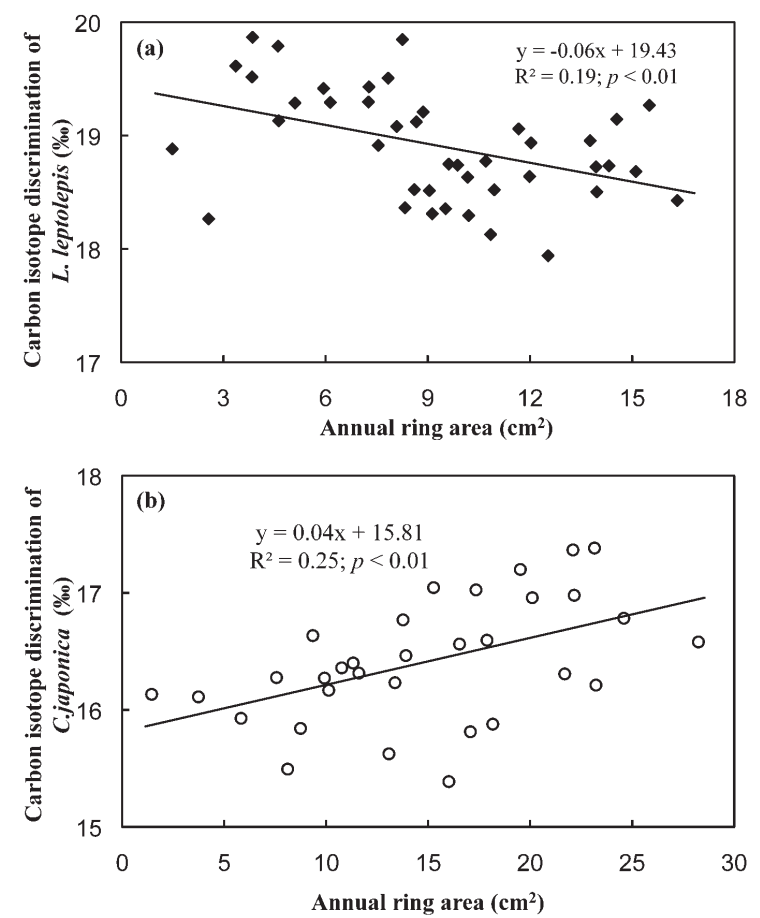

Fig. 5. Regression analysis between tree ring area and carbon isotope discrimination for the entire growth period 1966 to 2007 for L. leptolepis (a), 1978 to 2009 for $C$. japonica (b). concentration and precipitation $\mathrm{pH}$ but not with temperature, precipitation, and $\mathrm{O}_{3}$ concentration (data not shown). There were linear relationships between annual ring area and $\Delta$ for both species across the entire growth period (Fig. 5).

\section{Tree ring $\delta{ }^{15} \mathrm{~N}, \mathrm{~N}$ concentration and $\mathrm{Ca}: \mathrm{Al}$ ratio}

Tree ring $\delta^{15} \mathrm{~N}$ of $L$. leptolepis decreased significantly with time $(p<0.001)$ and varied between $4.2 \%$ and $-2.9 \% ; \delta^{15} \mathrm{~N}$ of $C$. japonica increased significantly with time $(p<0.001)$ and varied between $-8.5 \%$ and $-4.8 \% 0$ (Fig. 6a). Total $\mathrm{N}$ concentration was significantly greater $(p<0.01)$ in C. Japonica than L. leptolepis and fluctuated between 1.5 to $2.8 \mathrm{~g} \mathrm{~N} \mathrm{~kg}^{-1}$ and 0.2 to $1.8 \mathrm{~g} \mathrm{~N} \mathrm{~kg}^{-1}$, respectively (Fig. 6b).

Calcium concentrations of $L$. leptolepis increased from $0.1 \mathrm{~g} \mathrm{~kg}^{-1}$ to $0.63 \mathrm{~g} \mathrm{~kg}^{-1}$ between 1966 and $2007(p<$ 0.001) (Fig. 7a); Al concentration varied between $0.01 \mathrm{~g}$ $\mathrm{kg}^{-1}$ and $0.04 \mathrm{~g} \mathrm{~kg}^{-1}$ with a significant temporal trend over the study period $(p<0.05)$ (Fig. $7 \mathrm{~b})$. Ca/Al fluctuated
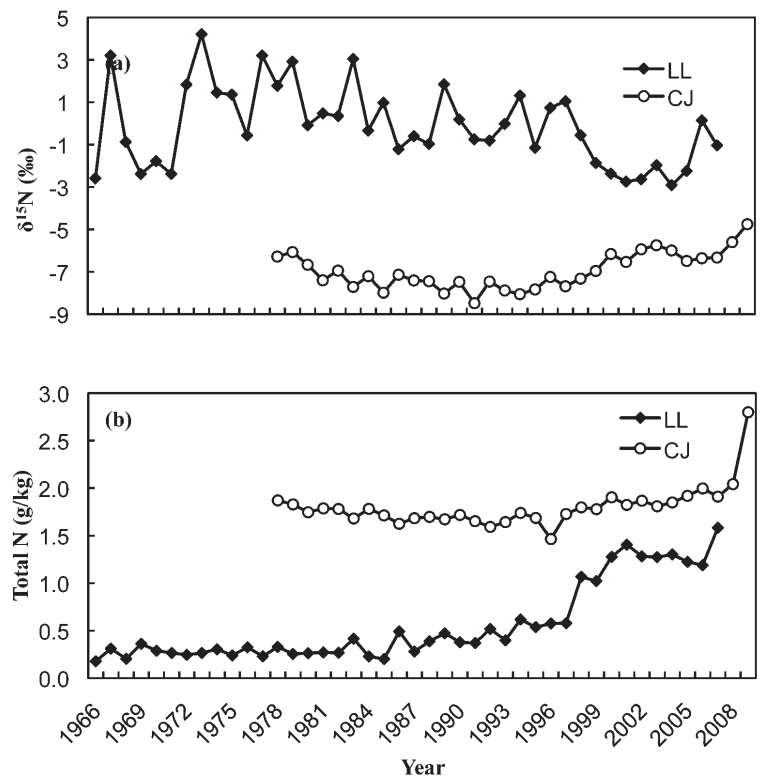

Fig. 6. Annual variations in $\delta^{15} \mathrm{~N}$ (a) and nitrogen concentration (b) in tree rings of two species. 
between 3.6 and 37.9 and did not show a systematic pattern with time (Fig.7c). In C. japonica, Ca concentrations decreased from $1.21 \mathrm{~g} \mathrm{~kg}^{-1}$ to $0.54 \mathrm{~g} \mathrm{~kg}^{-1}$; there was no significant pattern between 1978 and 2009 (Fig. 7a). $\mathrm{Al}$ concentration increased from $0.01 \mathrm{~g} \mathrm{~kg}^{-1}$ to $0.18 \mathrm{~g} \mathrm{~kg}^{-1}$. There was a significant temporal pattern $(p<0.001)$ and $\mathrm{Ca} / \mathrm{Al}$ decreased pattern $(p<0.001)$ from 87.4 in 1978 to 24.3 in 2008 (Fig. 7c).

\section{Relation between tree-ring chemistry and precipi- tation pH}

Between 1992 and 2009, precipitation pH was significantly correlated with $\delta^{13} \mathrm{C}, \delta{ }^{15} \mathrm{~N}$, and total $\mathrm{N}$ concentration in tree rings of both species but not with $\mathrm{Ca} / \mathrm{Al}$ (Table
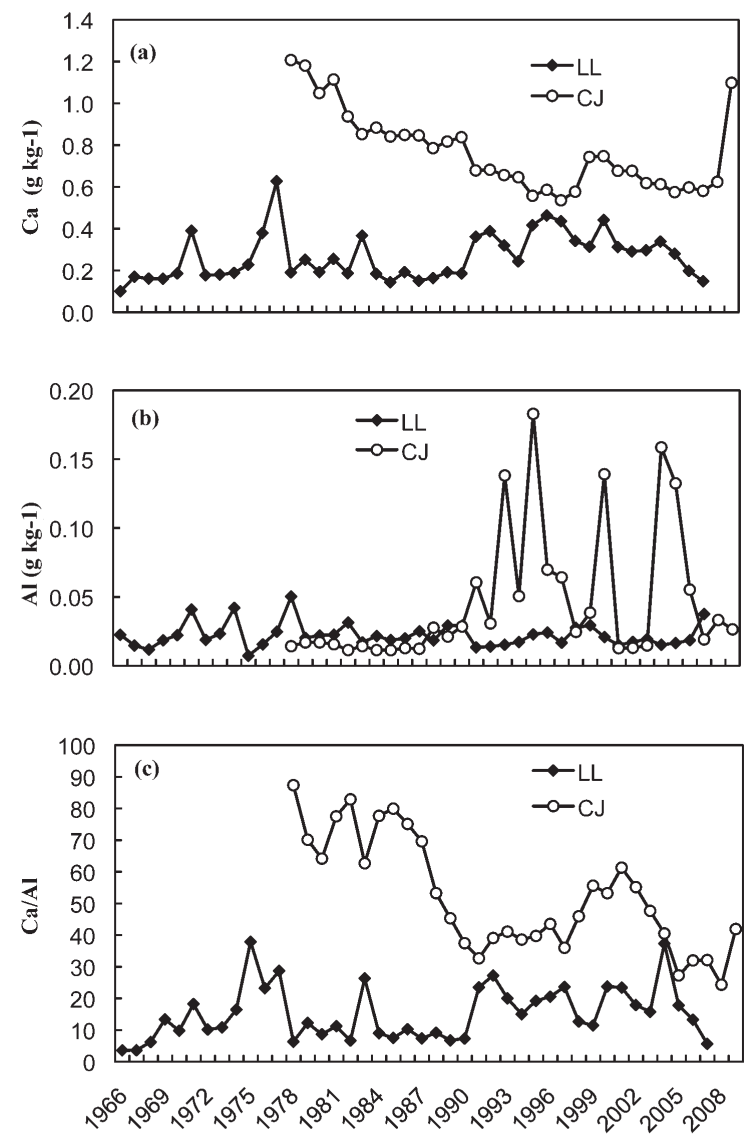

Fig. 7. Annual variations in $\mathrm{Ca}$ concentration (a), $\mathrm{Al}$ concentration (b), and $\mathrm{Ca}$ to $\mathrm{Al}$ (c) in tree rings of two species.
5; Fig. 8). The $\delta{ }^{13} \mathrm{C}$ of both species increased $(p<0.01)$ and $\mathrm{N}$ concentration decreased with increasing precipitation $\mathrm{pH}$ (Fig. 8a, 8c). The $\delta^{15} \mathrm{~N}$ in tree rings of L. leptolepis increased and of $C$. japonica decreased with increasing precipitation $\mathrm{pH}$ (Fig. 8b). Inter-correlations
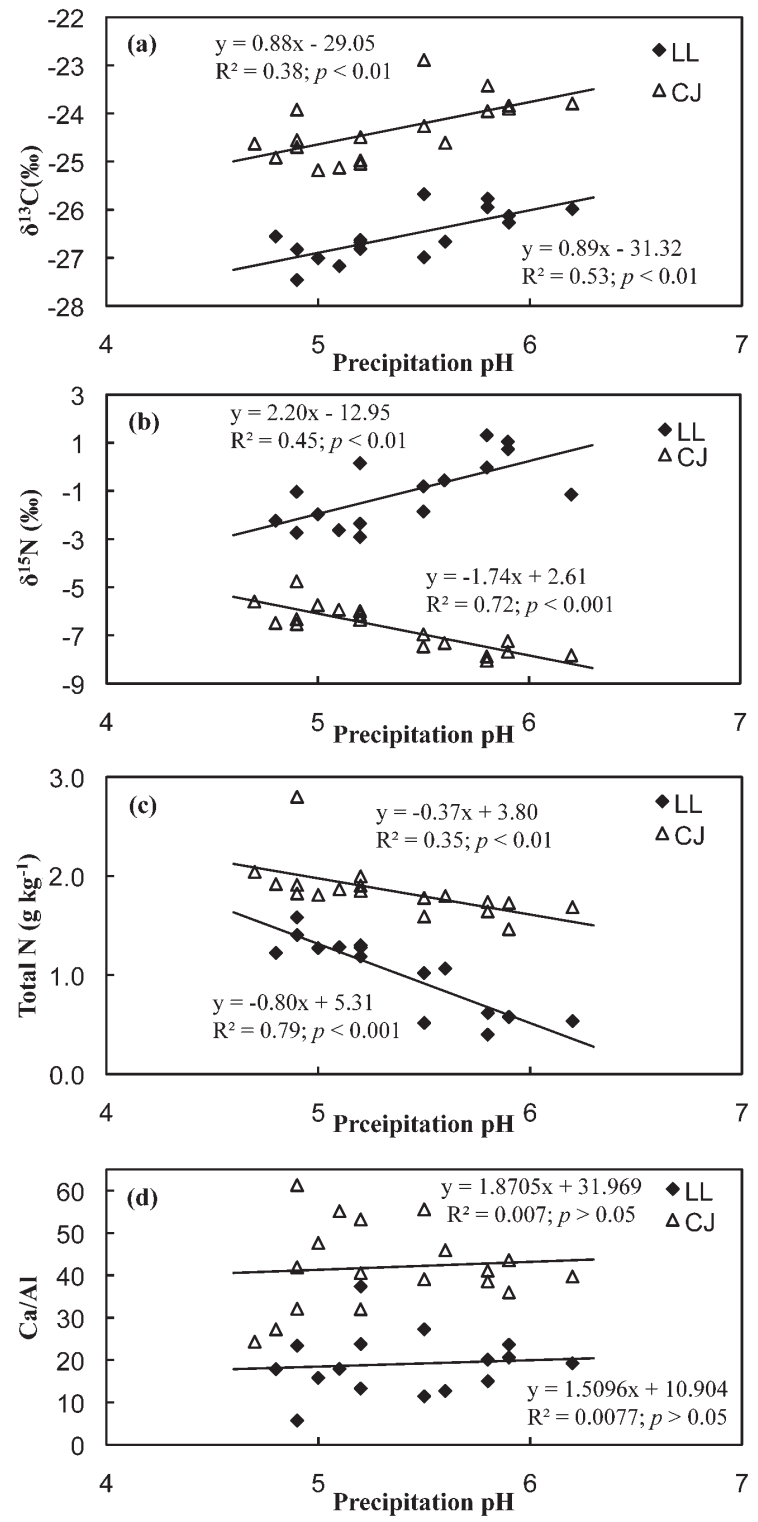

Fig. 8. Regression analysis between precipitation $\mathrm{pH}$ and carbon isotope (a), nitrogen isotope (b), nitrogen concentration (c), and $\mathrm{Ca} / \mathrm{Al}(\mathrm{d})$ of tree rings of two species.

Table 5. The relationship between tree ring chemistry of two species and precipitation $\mathrm{pH}$ in the study site

\begin{tabular}{lcc}
\hline \multirow{2}{*}{ Variable } & \multicolumn{2}{c}{ Pearson correlation coefficients } \\
\cline { 2 - 3 } & L. leptolepis ${ }^{\mathrm{a}}$ & C. japonic $^{\mathrm{a}}$ \\
\hline$\delta^{13} \mathrm{C} \times$ precipitation $\mathrm{pH}$ & $0.726^{* *}(16)$ & $0.620^{* *}(18)$ \\
$\delta{ }^{15} \mathrm{~N} \times$ precipitation $\mathrm{pH}$ & $0.672^{* *}(16)$ & $-0.849^{* * *}(18)$ \\
$\mathrm{N}$ concentration $\times$ precipitation $\mathrm{pH}$ & $-0.887^{* *}(16)$ & $-0.594^{* *}(18)$ \\
$\mathrm{Ca} / \mathrm{Al} \times$ precipitation $\mathrm{pH}$ & $0.088^{\mathrm{ns}}(16)$ & $0.084^{\mathrm{ns}}(18)$ \\
\hline
\end{tabular}

Values in the parentheses are the number of data points used for the correlation analysis

a The mean values of three trees were used for tree variables in the correlation analysis.

${ }^{\text {ns }}$ Not significant; ***p $p 0.001 ; * * p<0.01 ; * p<0.05$ 
between species were assessed using linear correlation for multiple regressions. For L. leptolepis, a regression model for the estimation of the history of precipitation $\mathrm{pH}(\mathrm{y})$ was developed using total $\mathrm{N}$ concentrations ( $\mathrm{y}=-$ $0.99 \mathrm{~N}$ concentration $\left.+6.38, r^{2}=0.79, p<0.001\right)$. For $C$. japonica, this equation was used to correlate to $\delta^{15} \mathrm{~N}(\mathrm{y}$ $\left.=-0.41 \delta^{15} \mathrm{~N}+2.58, r^{2}=0.72, p<0.001\right)$.

\section{DISCUSSION}

\section{Annual tree ring growth}

Annual ring growth varied markedly between and within species. The tree growth was affected by atmospheric pollutants, temperature, and soil fertility. Variations of annual ring growth of black spruce, tamarack (Choi et al., 2007) and red pine (Kwak et al., 2011) were influenced by changing soil nitrogen dynamics. In our study, the annual ring area increment of C. japonica was more sensitive to temperature and atmospheric pollutants in the site. A positive correlation between increased temperature and increased annual ring growth of $C$. japonica (Table 3) suggested that elevated temperature may increase the tree growth. Lebourgeois et al. (2005) reported that a positive effect of increased temperature on tree-ring growth may be modified by soil water capacity. Elevated temperature may be directly affecting tree growth and indirectly through interactions with other stressors and disturbances (Chmura et al., 2011). Although temperature between 1962 and 2009 increased from $0.1^{\circ} \mathrm{C}$ to $1.5^{\circ} \mathrm{C}$ (Fig 2a) at the study site, temperature has been claimed to be relatively unimportant for tree growth in this site (Luong et al., 2013).

For $C$. japonica, there was a negative correlation between increased $\mathrm{CO}_{2}$ concentration and annual ring growth, which is possibly linked to stomatal closure (Choi and Lee, 2012). This result is consistent with reductions in tree growth and increased $\mathrm{CO}_{2}$ concentration (Clark et al., 2003). Elevated atmospheric $\mathrm{CO}_{2}$ may be responsible for changes in tree growth rings (Luong et al., 2013). A significant correlation between $\mathrm{NO}_{2}$ concentration and annual ring area of this species (Table 3) may generally form $\mathrm{N}$ deposition (Bytnerowicz et al., 2007; Kwak et al., 2011; Luong et al., 2013). N deposition originating from $\mathrm{NO}_{2}$ is claimed to be the most important factor affecting tree growth (Bytnerowicz et al., 2007; Tomlinson, 2003). The rate of forest decline of $P$. densiflora in Japan has been shown to be negatively correlated with atmospheric $\mathrm{NO}_{2}$ concentration (Kume et al., 2000). Therefore, increases in annual growth of $C$. japonica at the study site may be cause of interactions among increased availability of $\mathrm{CO}_{2}$, elevated nitrogen deposition, and increased temperature (Bytnerowicz et al., 2007). The effects of $\mathrm{SO}_{2}$ concentration on annual ring area of both species (Table 3) could be due to the acid deposition (Kwak et al., 2011).Decreases in atmospheric $\mathrm{SO}_{2}$ concentration due to national policy were not considered sufficiently high to affect tree growth (Kume et al., 2000). The growth of L. leptolepis has been declining since 1989 due to acid deposition from fossil fuel combustion at the site (Tomlinson, 2003; Luong et al., 2013).

\section{$\delta{ }^{13} \mathrm{C}$ in tree rings}

The decreasing pattern of $\delta{ }^{13} \mathrm{C}$ in tree rings of the two species (Fig 4a) has been ascribed to decreases in $\delta{ }^{13} \mathrm{C}$ of atmospheric $\mathrm{CO}_{2}$ due to anthropogenic emissions of $\mathrm{CO}_{2}$ from fossil fuel combustion (McCarroll and Loader, 2004).However in this study, no significant correlation was noted between $\delta{ }^{13} \mathrm{C}$ and the atmospheric $\mathrm{CO}_{2}$ concentrations from 1999 to 2009 (Table 4). The effect of increased atmospheric $\mathrm{CO}_{2}$ concentration from fossil fuel combustion on decreasing $\delta{ }^{13} \mathrm{C}$ in tree rings may have been muted to some degree by climate and air pollution. There was a negative correlation between $\delta{ }^{13} \mathrm{C}$ of both species and temperature; this can be attributed to decreases in $\delta{ }^{13} \mathrm{C}$, because of the effect of stomatal conductance (Choi et al., 2005). Increased temperature at the site may increase $\mathrm{C}$ isotope discrimination (leading to a more negative $\delta{ }^{13} \mathrm{C}$ ) by increasing stomatal conductance (Warren and Dreyer, 2006).

A significant correlation between atmospheric $\mathrm{SO}_{2}$ concentration and tree-ring $\delta^{13} \mathrm{C}$ of both species (Table 4) resulted in impaired photosynthesis and reduced growth because of the history of air pollution (Martin and Sutherland, 1990). A negative correlation between increased atmospheric $\mathrm{NO}_{2}$ concentrations and decreased $\delta{ }^{13} \mathrm{C}$ of both species may be related to decreased carboxylation rate and increase $\mathrm{C}_{\mathrm{i}} / \mathrm{C}_{\mathrm{a}}$ due to the fertilization effect (Livingston et al., 1999; Choi and Lee, 2012). The relationship between $\mathrm{O}_{3}$ and $\delta^{13} \mathrm{C}$ of $L$. leptolepis may inhibit photosynthesis by closing stomata and reducing $\mathrm{CO}_{2}$ diffusion into the leaf (Saurer et al., 1995). Therefore, these relationships showed an increase in carbon isotope discrimination (Fig. 4b) caused by stomatal closure (Farquhar et al., 1982), leading to a negative $\delta^{13} \mathrm{C}$ under nutrient limited conditions (Livingston et al., 1999); this may affect tree growth.

The regression analysis between annual ring area and $\Delta$ (Fig. 5) revealed that the growth of both species was different. For L. leptolepis, a negative correlation between annual ring area and $\Delta(p<0.01)$ indicated that carboxylation rate played a more important role than stomatal conductance (Fig. 5a) and was the primary mechanism governing photosynthesis (Livingston et al., 1999; Viet et al., 2013). This observation is supported by the lower foliar $\mathrm{N}$ concentration of L. leptolepis than C. japonica (Table 2) because of the effects of atmospheric pollutants on $\Delta$ of $L$. leptolepis. Therefore, the decline in growth of $L$. leptolepis was affected more by carboxylation rate than by stomatal limitation (Viet et al., 2013). This may lead to an increase in $\Delta$ via maintaining high $\mathrm{C}_{\mathrm{i}} / \mathrm{C}_{\mathrm{a}}$ due to nutrient limitations, rather than other factors (Farquhar et al., 1982; Choi et al., 2007).

For $C$. japonica, a positive correlation between annual ring area and $\Delta$ with time (Fig. $5 \mathrm{~b}$ ) implied that stomatal conductance rather than carboxylation rate was the predominant mechanism influencing photosynthesis and tree growth; i.e. increases in stomatal conductance enhanced photosynthesis by supplying $\mathrm{CO}_{2}$ (Farquhar et al., 1989; Farquhar et al., 1982). The better growth of C. japonica can make it more susceptible to atmospheric pollutants, because of the large leaf surface area 
for their interception (Viet et al., 2013), and $\Delta$ was not affected by environmental variables that maintain lower $\mathrm{C}_{\mathrm{i}} / \mathrm{C}_{\mathrm{a}}$, leading to smaller $\Delta$.

These results are evidence that the tree-ring $\delta^{13} \mathrm{C}$ of $L$. leptolepis and C. japonica in this study was affected more by atmospheric environmental variables than observed for P. densiflora (Kwak et al., 2011), Betulapendula (Saurer et al., 1995), and Pseudotsuga menziesii (Martin and Sutherland, 1990).

\section{$\delta{ }^{15} \mathbf{N}, \mathbf{N}$ concentration, and $\mathrm{Ca} / \mathrm{Al}$ in tree rings}

The trend of decreasing $\delta^{15} \mathrm{~N}$ in L. leptolepis (Fig. 6a) was consistent with previous studies that indicated increased deposition of $\mathrm{N}$ depleted in ${ }^{15} \mathrm{~N}$ (Poulson et al., 1995; Choi et al., 2005; Savard et al., 2009). For example, Poulson et al. (1995) reported a decreasing pattern over time of $\delta^{15} \mathrm{~N}$ in tree rings of Tsuga candensis and Choi et al. (2005) a decrease in P. densiflora from $+2.0 \%$ in 1990 to $-1.0 \%$ in 2000. Savard et al. (2009) found similar trends with Fagus grandifolia and Pinus strobus. These patterns reflected the regional $\mathrm{N}$ deposition rates. In our study, the decrease in $\delta^{15} \mathrm{~N}$ in $L$. leptolepis can be seen as a record of long-term anthropogenic impacts of deposition of ${ }^{15} \mathrm{~N}$-depleted $\mathrm{N}$ compounds (Bukata and Kyser, 2007; Savard et al., 2009; Kwak et al., 2011). While $\delta^{15} \mathrm{~N}$ in tree rings of $C$. japonica significantly increased over time, this pattern was consistent with the studies of Bukata and Kyser (2005) and Hietz et al. (2010) who reported that increases in tree ring $\delta{ }^{15} \mathrm{~N}$ values can be related to disturbance by fertilization with $\mathrm{N}$ and logging. Increases in $\delta^{15} \mathrm{~N}$ in tree rings by $1.5-2.5 \% 0$ can be related to changes in forest dynamics and production (Hietz et al., 2010) and are consistent with increased $\delta^{15} \mathrm{~N}$ in tree rings of C. japonica. The increase in $\delta^{15} \mathrm{~N}$ of $C$. japonica could result from the loss of ${ }^{15} \mathrm{~N}$-depleted compounds through denitrification, ammonia volatilization or nitrate leaching (Elhani et al., 2005).

Although the increase of $\mathrm{N}$ concentration over time of both species was significant (Fig. 6b), N concentration in tree rings may not be a reliable indicator of timerelated information regarding $\mathrm{N}$ availability due to the potential movement of $\mathrm{N}$ towards the outermost rings (Poulson et al., 1995; Bukata and Kyser, 2005). The trends in tree-ring $\mathrm{N}$ and $\mathrm{N}$ isotopic composition of both species may be due to changes in tree dynamics via photosynthetic capacity (Choi et al., 2007).

$\mathrm{Ca} / \mathrm{Al}$ ratios of $L$. leptolepis did not show a significant temporal pattern despite the consistently increasing Ca concentration in tree rings (Fig. 7a, 7c). This was due to low $\mathrm{Al}$ concentrations (Fig. 7b) that offset $\mathrm{Ca}$ increases in tree rings (DeWalle et al., 1999). Increased Ca concentrations in tree rings may be due to increased numbers of ion exchange sites (Shortle et al., 1995) or indicate a physiological response within the tree rather than an actual change in bioavailability (Read, 2008). In contrast, a significant difference in $\mathrm{Ca} / \mathrm{Al}$ ratios in $C$. japonica trees was related to a decreasing trend, consistent with decreases in $\mathrm{Ca}$ and increases in $\mathrm{Al}$ concentrations (Fig. 7). However, both increasing and decreas- ing Ca concentration may be relative to the binding capacity of acid deposition (Bondietti and Momoshima, 1990; Lee et al., 2011). The radial concentration trends of $\mathrm{Ca}^{2+}$, $\mathrm{Al}^{3+}$, and $\mathrm{Ca} / \mathrm{Al}$ ratios in C. japonica was a higher increase than that of L. leptolepis. Bondietti and Momoshima (1990) suggested that the increase in cations present in wood formed is coincident with rapid increases in $\mathrm{SO}_{x}$ and $\mathrm{NO}_{\mathrm{x}}$ deposition and with increases in radial growth increment; otherwise, the decrease in cations in wood formed is coincident with a decline in radial growth increment. This is the reason why in our study tree ring growth of C. japonica was higher than that of L. leptolepis.

\section{Relationship between tree ring chemistry and pre- cipitation $\mathbf{p H}$}

Tree ring $\delta{ }^{13} \mathrm{C}, \quad{ }^{15} \mathrm{~N}$ and $\mathrm{N}$ concentration of both species were significantly $(p<0.01)$ correlated with precipitation pH between 1992 and 2009 (Table 5; Fig. 8). The positive correlation between $\delta^{13} \mathrm{C}$ and decreased precipitation $\mathrm{pH}$ (Fig. 8a) had been shown to be related with the deleterious effects on photosynthesis by the $\mathrm{H}+$ input from acid rain (Shan, 1998) due to the co-emission of $\mathrm{NO}_{2}$ and $\mathrm{SO}_{2}$ (Fig. 2c) with ${ }^{13} \mathrm{C}$-depleted $\mathrm{CO}_{2}$ from fossil fuel combustion. A simulated acid rainfall ( $\mathrm{pH}$ 2.3) experiment with $P$. densiflora degraded chlorophyll in the pheophytin and reduced the carboxylation rate (Shan, 1998) in a way that could cause a decrease of $\delta^{13} \mathrm{C}$ in plant tissue. In this study, the annual mean precipitation pH was over 5.0 (Fig. 2b). An effect of $\mathrm{H}^{+}$in precipitation on $\delta{ }^{13} \mathrm{C}$ could also contribute to the positive correlation between precipitation $\mathrm{pH}$ and tree ring $\delta{ }^{13} \mathrm{C}$. This result contrasts to the tree ring $\delta{ }^{13} \mathrm{C}$ of $P$. densiflora of Kwak et al. (2009b) who indicated it was negatively correlated with precipitation $\mathrm{pH}$ in industrial areas. Therefore, $\delta{ }^{13} \mathrm{C}$ in tree rings of $L$. leptolepis and $C$. japonica may be useful as an indicator of precipitation $\mathrm{pH}$.

A negative correlation between increased $\mathrm{N}$ concentration in tree rings of both species and precipitation $\mathrm{pH}$ (Table 5; Fig. 8c) might provide information on $\mathrm{N}$ deposition (Choi et al., 2005), because one of the source compounds of precipitation acidity is fossil fuel combustion emission of, not only $\mathrm{CO}_{2}$, but also $\mathrm{NO}_{\mathrm{x}}$. This relationship has been observed for various tree species in different regions (Poulson et al., 1995; Bukata and Kyser, 2005; Kwak et al., 2009b) and suggests that total N concentration in tree rings can serve as a semi-quantitative surrogate of soil $\mathrm{N}$ availability at the time the tree ring was formed (Kwak et al., 2009b).

Although, the relationship between $\delta^{15} \mathrm{~N}$ in tree rings and precipitation $\mathrm{pH}$ was different between the two species (Fig 8b; Table 5), both negative and positive correlations between $\delta{ }^{15} \mathrm{Nand}$ precipitation $\mathrm{pH}$ can be linked to $\mathrm{N}$ deposition (Kwak et al., 2009b; Kwak et al., 2011) due to the $\mathrm{H}^{+}$input from acid rain (Shan, 1998). N deposition was depleted ${ }^{15} \mathrm{~N}$ to the increase in $\mathrm{N}$ concentrations of annual growth rings. The nitrogen content from this acid precipitation can be sufficient to stimulate tree growth and can be to override any expected negative effect 
(Shan, 1998). Thus tree ring $\delta^{15} \mathrm{~N}$ and $\mathrm{N}$ concentrations of both species can reveal the historical precipitation $\mathrm{pH}$.

The lack of correlation between tree ring $\mathrm{Ca} / \mathrm{Al}$ ratios and precipitation $\mathrm{pH}$ in both species (Table 5) was probably due to the characteristics of the local environment and its pollution history (Read, 2008). Soil pH fluctuated from 4.00 to 4.35 (Table 1 ) and the soil was acidic (Ito et al., 2011) at the site. This suggested that soil acidification had progressed to some degree (Kwak et al., 2009a) and is consistent with previous findings for $Q$. alba, Q. prunus (Read, 2008), and P. densiflora (Kwak et al., 2011).

An equation of precipitation $\mathrm{pH}$ was correlated with tree-ring $\mathrm{N}$ of L. leptolepis and $\delta^{15} \mathrm{~N}$ of $C$. japonica to estimate precipitation $\mathrm{pH}$ using tree-ring chemistry. These correlations reflected the influence of ${ }^{15} \mathrm{~N}$-depleted $\mathrm{N}$ compounds deposited via precipitation (Kwak et al., 2009b). Decreasing precipitation pH (Fig. 2b) may reflect increased $\mathrm{N}$ deposition originating from $\mathrm{NO}_{\mathrm{x}}$ emissions that are known to be depleted in ${ }^{15} \mathrm{~N}$ relative to the soil mineral $\mathrm{N}$ due to soil acidification (Kwak et al., 2011) with an average $\mathrm{pH}$ of 4.35 (Ito et al., 2011). In our study, mean $\mathrm{pH}$ ranged from 4.00 to 4.35 (Table 1 ). Changes in regional $\mathrm{H}^{+}$or the soil $\mathrm{pH}$ can affect the $\delta^{15} \mathrm{~N}$ value of nitrogen available to the tree (Bukata and Kyser, 2005) and may be attributed to changes in the nitrogen cycle (Choi et al., 2007). This has altered the growth and forest structure and function. However, the applicability of tree-ring $\mathrm{N}$ concentration and $\delta^{15} \mathrm{~N}$ to estimate historical precipitation $\mathrm{pH}$ in forest ecology at the study site would be difficult to predict, because multiple stressors were acting in different directions on the $\delta^{15} \mathrm{~N}$ values of bioavailable nitrogen (Bukata and Kyser, 2005).

\section{CONCLUSION}

Tree ring growth of both species was differently correlated with environmental factors. Annual ring growth rate of $C$. japonica was higher than that of L. leptolepis, because of species differences in the risk from the longterm effects of acid deposition from fossil fuel combustion. The decline in growth of L. leptolepis may be affected more by carboxylation rate rather than by stomatal conductance due to the effects of air pollution on $\mathrm{C}$ isotope discrimination that may lead to nutrient limitation. A better growth of C. japonica might be the interception of atmospheric pollutants, because increases in stomatal conductance enhanced photosynthesis by supplying $\mathrm{CO}_{2}$. Decreased $\delta{ }^{13} \mathrm{C}$ in tree rings of both species at the site may reflect increased $\mathrm{N}$ deposition originating from NOx emission that is typically depleted in ${ }^{15} \mathrm{~N}$ due to soil acidification. The increase and decrease in $\mathrm{Ca}, \mathrm{Al}$ cations and $\mathrm{Ca} / \mathrm{Al}$ present in tree rings of $C$. japonica and L. leptolepis was coincident with increases and decreases in radial increment due to $\mathrm{SO}_{\mathrm{x}}$ and $\mathrm{NO}_{\mathrm{x}}$ deposition. Therefore, tree ring $\delta{ }^{13} \mathrm{C}, \delta{ }^{15} \mathrm{~N}$, and $\mathrm{N}$ concentrations may indicators for historical precipitation $\mathrm{pH}$, because air pollutants affected $\delta{ }^{13} \mathrm{C}$ and the mobility of $\mathrm{N}$ in tree rings provided information on $\mathrm{N}$ deposition from acid rain. However, estimation of historical precipitation $\mathrm{pH}$ was difficult to apply to tree ring $\delta{ }^{15} \mathrm{~N}$ of $C$. japonica and $\mathrm{N}$ concentration of $L$. leptolepis, because of various impacts on $\delta{ }^{15} \mathrm{~N}$ values and $\mathrm{N}$ availability. The problem of acid deposition may reflect greater risk of decline in L. leptolepis forest than for C. japonica forest.

\section{ACKNOWLEDGMENTS}

This study was supported by a grant (code: NRF2013R1A1A2064761) from National Research Foundation of Korea.

\section{REFERENCES}

Bondietti, E. A. and N. Momoshima 1990 A historical perspective on divalent cation trends in red spruce stemwood and the hypothetical relationship to acidic deposition. Can. J. For. Res., 20: $1850-1858$

Bukata, A. and T. K. Kyser 2005 Response of the nitrogen isotopic composition of tree-rings following tree-clearing and land-use change. Environ. Sci. Technol., 39: 7777-7783

Bukata, A. and T. K. Kyser 2007 Carbon and nitrogen isotope variations in tree rings as records of perturbations in regional carbon and nitrogen cycle. Environ. Sci. Technol., 41: 1331-1338

Bytnerowicz, A., K. Omasa and E. Paoletti 2007 Integrated effects of air pollution and climate change on forests: A northern hemisphere perspective. Environ. Pollut., 147: 438-445

Chmura, D. J., P. D. Anderson, G. T. Howe, C. A. Harrington, J. E. Halofsky, D. L. Peterson, D. C. Shaw and J. B. St. Clair 2011 Forest responses to climate change in the north western United States: Ecophysiological foundation for adaptive management. Forest Ecol. Manag., 261: 1121-1142

Choi, W. J., S. X Chang and J. S. Bhatti 2007 Drainage affects tree growth and $\mathrm{C}$ and $\mathrm{N}$ dynamics in a Minerotropic Peatland. Ecology, 2: 443-453

Choi, W. J. and K. H. Lee 2012 A short overview on linking annual tree ring carbon isotopes to historical changes in atmospheric environment. Forest Sci. Technol., 8: 73-78

Choi, W. J., S. M. Lee, S. X. Chang and H. M. Ro 2005 Variations of $\delta{ }^{13} \mathrm{C}$ and $\delta{ }^{15} \mathrm{~N}$ in Pinus densiflora tree rings and their relationship to environmental changes in Eastern Korea. Water, Air, Soil Pollut., 164: 173-187

Clark, D. A., S. C. Piper, C. D. Keeling and D. B. Clark 2003 Tropical rain forest tree growth and atmospheric carbon dynamics linked to interannual temperature variation during 1984-2000. Proc. Na.t Acad. Sci., 100: 5852-5857

DeWalle, D. R., J. S. Tepp, B. R. Swistock, W. E. Sharpe and P. J. Edwards 1999 Tree ring cation response to experimental watershed acidification in West Virginia and Maine. J. Environ. Qual., 28: 299-309

Elhani, S, J. M. Guehl, C. Nys, J. F. Picard and J. L. Dupouey 2005 Impact of fertilization on tree ring $\delta^{15} \mathrm{~N}$ and $\delta^{13} \mathrm{C}$ in beech stands: a retrospective analysis. Tree Physio.l., 25: 1437-1446

Farquhar, G. D., J. R. Ehleringer and K. T. Hubick 1989 Carbon isotope discrimination and photosynthesis. Ann. Rev. Plant Physiol. Plant Mol. Biol., 40: 503-537

Farquhar, G. D., M. H. O'Leary and J. A. Berry 1982 On the relationship between carbon isotope discrimination and the intercellular carbon dioxide concentration in leaves. Aust. J. Plant Physio., 19: 121-37

Feng, X. 1998 Long-term $\mathrm{C}_{\mathrm{i}} / \mathrm{C}_{\mathrm{a}}$ responses of trees in western North America to atmospheric $\mathrm{CO}_{2}$ concentration derived from carbon isotope chronologies. Oecologia, 117: 19-25

Hietz, P., O. Dünisch and W. Wanek 2010 Long term trends in nitrogen isotope composition and nitrogen concentration in Brazilian rainforest trees suggest changes in nitrogen cycle. Environ. Sci. Technol., 44: 1191-1196

Hirano, Y., T. Mizoguchi and I. Brunner 2007 Root parameters of forest tree as sensitive indicators of acidifying pollutants: a 
review of research of Japanese forest trees. J. Forest Res., 12: 134-142

Ito, K., Y. Uchiyama, N. Kurokami, K. Sugano and Y. Nakanishi 2011 Soil acidification and decline of trees in forests within the precincts of Shrines in Kyoto (Japan). Water, Air, Soil Pollut., 214: 197-204

Kume, A., N. Tsuboi, T. Satomura, M. Suzuki, M. Chiwa, K. Nakane, N. Sakurai, T. Horikoshi and H. Sakugawa 2000 Physiological characteristics of Japanese red pine, Pinus densiflora Sieb. Et Zucc., in declined forests at Mt. Gokurakuji in Hiroshima Prefecture, Japan. Trees, 14: 305-311

Kwak, J. H., S. S. Lim, S. X. Chang, K. H. Lee and W. J. Choi 2011 Potential use of $\delta{ }^{13} \mathrm{C}, \quad{ }^{15} \mathrm{~N}, \mathrm{~N}$ concentration, and $\mathrm{Ca} / \mathrm{Al}$ of Pinus densiflora tree rings in estimating historical precipitation pH. J. Soil Sediment, 11: 709-721

Kwak, J. H., S. S. Lim, H. J. Park, S. I. Lee, K. H. Lee, H. Y. Kim, S. X. Chang, S. M. Lee, H. M. Ro and W. J. Choi 2009 Relating tree ring chemistry of Pinus densiflora to precipitation acidity in an industrial area of South Korea. Water, Air, Soil Pollut., 199: $9-106$

Kwak, J. K, W. J. Choi, S. S. Lim and M. A. Arsha $2009 \quad \delta{ }^{13}$ C, $\delta^{15} \mathrm{~N}, \mathrm{~N}$ concentration, and $\mathrm{Ca} / \mathrm{Al}$ ratios of forest samples from Pinus densiflora stands in rural and industrial areas. Chem. Geol., 264: 385-393

Lebourgeois F., N. Breda, E. Ulrich and A. Granier 2005 Climatetree-growth relationships of European beech (Fagus sylvatica L.) in the French Permanent Plot Network (RENECOFOR). Trees, 19: 385-401

Lee, K. S., D. V. Hung, J. H. Kwak, S. S. Lim, K. H. Lee and W. J. Choi 2011 Tree ring $\mathrm{Ca} / \mathrm{Al}$ as an indicator of historical soil acidification of Pinus densiflora forest in Southern Korea. Korean J. Environ. Agric., 3: 229-233

Livingston, N. J., R. D. Guy, Z. J. Dun and G. J Ethier 1999 The effects of nitrogen stress on the stable carbon isotope composition, productivity and water use efficiency of while spruce (Piceaglauca (Moench) Voss) seedlings. Plant, Cell Environ., 22: 281-289

Loader, N. J., I. Robertson and D. McCarroll 2003 Comparison of stable carbon isotope ratios in the whole wood, cellulose and lignin of oak tree-rings. Palaeogeogr. Palaeoclimato.l Palaeoecol., 196: 395-407

Luong, T. H., K. S. Jang, W. J. Choi and K. H. Lee 2013 Effects of atmospheric environmental changes on annual ring growth of
Cryptomeria japonica in Southern Korea. J. Ecol. Environ. 36: $31-38$

Martin, B. and E. K. Sutherland 1990 Air pollution in the past recorded in width and stable carbon isotope composition of annual growth rings of Douglas-fir. Plant, Cell Environ., 13 839-844

McCarroll, D. and N. J. Loader 2004 Stable isotopes in tree rings. Quat. Sci. Rev., 23: 771-801

Ministry of Environment of Korea 2010 Annual reports of ambient air quality in Korea. Ministry of Environment, Seoul

Poulson, S. R., C. P. Chamberlain and A. J. Friedland 1995 Nitrogen isotope variation of tree rings as a potential indicator of environmental change. Chem. Geol., 125: 307-315

Read, Q. D. 2008 Soil and tree ring chemistry changes in an oak forest. Institute for the Environment Highlands Field Site 2008 Internship Research Reports. Highlands Biological Station, North Carolina, pp. 56-65

Roden, J. S., D. R. Bowling, N. G. Mcdowell, B. J. Bond and J. R. Ehleringer 2005 Carbon and oxygen isotope ratios of tree ring cellulose a long a precipitation transect in Oregon, United State. J. Geophys. Res. Biogeosci., 110: 1-11

Saurer, M., S. Maurer, R. Matyssek, W. Landolt, M. S. GünthardtGoerg and U. Siegenthaler 1995 The influence of ozone and nutrition on $\delta^{13} \mathrm{C}$ in Betulapendula. Oecologia, 103: 397-406

Savard, M. M., C. Bégin and A. Smirnoff 2009 Tree ring nitrogen isotopes reflect anthropogenic NOx emissions and climate effects. Environ. Sci. Technol., 43: 604-609

Shan, Y. 1998 Effects of simulated acid rain on Pinus densiflora: inhibition of net photosynthesis by the pheophytization of chlorophyll. Water, Air, Soil Pollut., 103: 121-127

Shortle, W. C., K. T. Smith, R. Minocha and A. Alexey 1995 Similar patterns of change in stemwood calcium concentration in red spruce and Siberian fir. J. Biogeogr., 22: 467-473

Tomlinson, G. H. 2003 Acidic deposition, nutrient leaching and forest growth. Biogeochemistry, 65: 51-81

Viet, H. D., J. H. Kwak, K. S. Lee, S. S Lim, M. Matsushima, S. X. Chang, K. H. Lee and W. J. Choi 2013 Foliar chemistry and tree ring $\delta{ }^{13} \mathrm{C}$ of Pinus densiflora in relation to tree growth along a soil pH gradient. Plant Soil, 363: 101-112

Warren, C. R. and E. Dreyer 2006 Temperature response of photosynthesis and internal conductance to $\mathrm{CO}_{2}$ : results from two independent approaches. J. Exp. Bot., 12: 3057-3067 